\title{
Effects of crossbreeding Hungarian Merino sheep with Suffolk and Ile de France on carcass traits
}

\author{
FERENC PAJOR, EDINA LÁCZÓ, ORSOLYA ERDŐS and PÉTER PÓTI
}

Institute of Animal Husbandry, Szent István University, Gödöllő, Hungary

\begin{abstract}
In this examination, Hungarian Merino (ram $n=30$, ewe $n=30$ ), Hungarian Merino $\times$ lle de France $F_{1}$, and Hungarian Merino $\times$ Suffolk $F_{1}$ (ram $n=15$, ewe $n=15$ ) lambs were used to evaluate the effect of crossbreeding on carcass characteristics and composition. We examined fattening performances and the following carcass traits: dressing percentage, weight of valuable carcass cuts, percentage of valuable meat, bone to meat ratio, and as well as meat conformation and fat cover (S/EUROP grading). In the present investigation, the weight at slaughter was fixed between $31-32 \mathrm{~kg}$ approximately, thus ensuring, weight would not affect carcass composition. Standardizing carcass weight allowed us to spot differences due to genotype and gender. The best results of fattening performance showed the Hungarian Merino $\times$ Ile de France $F_{1}$ lambs (358 g/day). The tested crossed genotypes had not greatly influence dressing percentage and warm carcass weight, but the best percentage valuable carcass cuts had Hungarian Merino $\times$ Suffolk $F_{1}(83.37 \%)$. The best percentage of valuable meat presented (77.76\%) the Hungarian Merino $\times$ lle de France $F_{1}$ lambs. The best meat conformation and fat covered showed the Hungarian Merino $\times$ Suffolk $F_{1}$ lambs. Hungarian Merinos showed less favourable results. To the summarising, the Suffolk and lle de France improved the Hungarian Merino's fattening performance, slaughter value and ability of market over $30 \mathrm{~kg}$ live weight, therefore there were both breeds suggest with crossing.
\end{abstract}

Keywords: sheep, crossing, fattening, slaughter performance, S/EUROP qualifications, Hungarian Merino, Suffolk, Ile de France

\section{Zusammenfassung}

\section{Mast und Schlachtleistungen von Lämmern aus der Kreuzung Ungarischer Merino mit Suffolk und Ile de France Schafen}

Zur Prüfung des Einflusses der Kreuzung auf die Mast- und Schlachtleistung wurden jeweils 30 männliche und weibliche Ungarische Merino und Ungarische Merino $\times$ lle de France $F_{1}$ sowie je 15 männliche und weibliche Ungarische Merino $\times$ Suffolklämmer $F_{1}$ untersucht. Verglichen wurden die tägliche Zunahme, die Zusammensetzung des Schlachtkörpers sowie die Ergebnisse der S/EUROP Klassifizierung bei den Tieren unterschiedlicher Genotypen. Um den Einfluss unterschiedlicher Schlachtgewichte auszuschließen wurden die Tiere aller Genotypen mit durchschnittlich 31-32 kg geschlachtet. Die besten Mastleistungen erreichten die Ungarische Merino $\times$ lle de France Lämmer mit $358 \mathrm{~g}$ täglicher Zunahme. Die Kreuzung ergab keinen wesentlichen Einfluss auf die 
Schlachtausbeute und das warme Schlachtkörpergewicht. Mit 83,4\% erreichten die Ungarische Merino $\times$ Suffolklämmer den höchsten Anteil wertvoller Fleischteilstücke und den höchsten Fleischanteil von 77,8\% die Ungarische Merino $\times$ Ile de France Lämmer. Die Ungarische Merino $\times$ Suffolklämmer zeigten beste Ergebnisse hinsichtlich Bemuskelung, Fleischigkeits- und Fettgewebeklasse. Zusammenfassend wird festgestellt, dass bei Schlachtgewichten über $30 \mathrm{~kg}$ die Leistungen der Ungarischen Merino hinsichtlich der Mastleistung, des Schlachtwertes und der Vermarktungsergebnisse durch die Kreuzung mit Suffolk bzw. Ile de France verbessert werden konnten und sich beide Rassen als Kreuzungspartner eignen.

Schlüsselwörter: Schaf, Kreuzung, Mast, Schlachtleistung, S/EUROP Klassifizierung, Ungarische Merino, Suffolk, lle de France

\section{Introduction}

The slaughter performances of lambs are known to vary by genotype, sex, the fattening conditions, and slaughter weight and age (KORMAN 2001, MARTYNIUK et al. 2001, POMPA-ROBORZYNSKI and KEDZIOR 2006). Sheep carcass has conventionally been qualified by boning and meat quality scores. This objective method has been implemented with the S/EUROP classification system based on visual (subjective) grading of carcass some years ago. By now, a good deal of experience has accumulated with the use of the S/EUROP system concerned lamb carcass-quality (LENGYEL et al. 1999, LIPECKA et al. 2001, PARAPONIAK and ROBORZYNSKI 2001). Reliability of the S/EUROP system for evaluation of lamb carcass quality has been investigated by TOLDI et al. (1999) and more recently by FREUDENREICH et al. (2001).

In Hungary, $90 \%$ of the income of sheep business is originated from lamb sales. Most of the lambs are exported at Easter, Christmas and at Ferragosto (15th August). In accordance to the strengthening market conditions the Hungarian sheep breeding is in a challenging environment where the competitiveness is sharper and difficult to sale.

Maintaining the level of revenues of Hungarian lamb export requires the competitiveness of this product, as well. Its realisation essentially takes improvement of meat production parameters (weight gain, body weight, slaughtering parameters). Increasing the revenues it is recommended to use meat type terminal breeds in commercial crossing with the marketing Hungarian Merino livestock (LENGYEL et al. 1999).

The performance of lamb and the quality of carcass are mainly determined by the breed itself (KEFELEGN et al. 1998). Pure breeds and crossings have significant role in production. Crossing from one generation to the other makes more and also heavier slaughtering lambs in comparison with pure breed production (ZUPP 2003). From the combination of simple crossing of two breeds all lambs should be fattened for slaughter, when heterosis is utilized (SUESS et al. 2000, ZUPP 2003). From the experiment of OSIKOWSKI and BORYS (1976), those lambs which originated from different meat type rams crossing with Merino ewes had better gain; Merino $\times$ lle de France F1 had shown $6.2 \%$, Merino $\times$ German Blackheaded F1 had shown $7.8 \%$ and Merino $\times$ Texel F1 had shown $8.8 \%$ extras in comparison with the pure-bred Merino lambs. Similar results received BROSTOWSKI and TANSKI (2006) and BRZOSTOWSKI et al. (2004). 
The aim of our experiment was to evaluate the Hungarian Merino breed and determine whether the Suffolk and lle de France breeds can exert a positive effect on the carcass characteristics and carcass S/EUROP qualification of Hungarian Merino lambs.

\section{Material and methods}

Within our experiment Hungarian Merino ( $n=30$ ram and ewe lambs, age at the start: $60 \pm 2.95$ day), Hungarian Merino $\times$ lle de France $F_{1}(n=15$ ram and ewe lambs, age at the start: $51.8 \pm 8.73$ day) and Hungarian Merino $\times$ Suffolk $F_{1}(n=15$ ram and ewe lambs, age at the start: $55.5 \pm 7.12$ day) genotype lambs were examined. It was part of a long-term scientific program (2003-2005) focusing to meat production system in sheep husbandry.

The experiments got executed at the Central Sheep Performance Station of Atkár, Hungary. The lambs were separated by sex and genotype. Littering was made with plenty of straw. Lambs were fed fattening feed, ad libitum. Feed contents were: $48 \%$ corn, $20 \%$ of wheat, $10 \%$ of lucerne meal, $10.5 \%$ soy meal, $4 \%$ sunflower meal, $4 \%$ bran and $3.5 \%$ of premix (KP9302). The crude content of feed is also present in Table 1.

Table 1

Composition of fed forage

Futterzusammensetzung

\begin{tabular}{lc}
\hline Component & \\
\hline Dry matter & $894 \mathrm{~g} / \mathrm{kg}$ forage \\
Crude ash & $58 \mathrm{~g} / \mathrm{kg}$ dry matter \\
Crude protein & $143 \mathrm{~g} / \mathrm{kg}$ dry matter \\
Crude fat & $26 \mathrm{~g} / \mathrm{kg}$ dry matter \\
Crude fibre & $59 \mathrm{~g} / \mathrm{kg}$ dry matter \\
Nitrogen-free extracts & $608 \mathrm{~g} / \mathrm{kg}$ dry matter \\
Digestible energy & $12.4 \mathrm{MJ}$ \\
$\mathrm{Ca}$ & $1.1 \%$ \\
$\mathrm{P}$ & $0.4 \%$ \\
$\mathrm{Na}$ & $0.3 \%$ \\
\hline
\end{tabular}

It was calculated the weight gain the lambs made during the experimental period. Lambs were starved $24 \mathrm{~h}$ following the fattening phase, and then their weight was measured, just before the slaughter. The process of the slaughter was skinning, removal of head, feet, guts and fat. Carcasses were classified post-slaughter for conformation and fat cover using the S/EUROP system. Classifying by the muscle built up was done by evaluation of body. Then the following parameters got measured: warm body weight, dressing percentage.

After $24 \mathrm{~h}$ chilling, the right carcass half was cutting up by the Australian standard method and dissected the body parts to meat and bone. After chilling and cutting, following traits were recorded: cold carcass weight, the proportion and weight of valuable carcass cuts, the bone-to-meat ratio in carcass cuts and the proportion and weight of valuable meats.

Data were analyzed with SPSS 14.0 statistical program package using the General Linear Model (GLM) procedure to perform an analysis of variance for each of the measured variables. The statistical model was as follows: 


$$
Y_{i j k}=\mu+B_{i}+G_{j}+(B+G) k+e_{i j k}
$$

where is $Y_{i j k}$ the value of the dependent variable, $\mu$ the overall mean, $B_{i}$ the effect of the genotype, $G_{j}$ the effect of gender, $(B+G) k$ the interaction genotype $\times$ gender and $e_{i j k}$ the random error.

\section{Results and discussion}

In the present investigation, the weight at slaughter was fixed between $31-32 \mathrm{~kg}$ approximately, thus ensuring, weight would not affect carcass composition. Standardizing carcass weight allowed us to spot differences due to genotype and gender. GUTIERREZ et al. (2005) standardized the carcass weight for evaluate the effect of crossbreeding on carcass characteristics and composition.

Among the examined genotypes of all, the weight gain of Hungarian Merino $\times$ Suffolk $F_{1}$ 's and the Hungarian Merino $\times$ lle de France $F_{1}$ lambs were the biggest $(352.06 \mathrm{~g} /$ day vs. $358.24 \mathrm{~g} /$ day), and the Hungarian Merino as last in the order (323.01 g/day). The Hungarian Merino $\times$ Suffolk crossed lambs weight gain corresponded with data published by SCHWULST, (1986) where found $346 \mathrm{~g} /$ day similar crossed lambs.

Concerning the average daily weight gain, Hungarian Merino lambs were $11 \%$ overdone by Hungarian Merino $\times$ lle de France $F_{1}, 9 \%$ by Hungarian Merino $\times$ Suffolk $F_{1}$.

The crossed genotypes tested did not greatly influence dressing percentage and warm carcass weight. These are in agreement with the findings of OSIKOWSKI and BORYS (1976), GUTIERREZ et al. (2004) and CLOETE et al. (2005).

Gender influenced the average weight gain. Ram groups had bigger average weight gain than ewe groups. Gender not influenced the dressing percentage and weight of warm carcass (Table 2).

Table 2

Least squares means \pm standard error of lamb slaughter data according to genotype and gender Mast- und Schlachtdaten nach Genotyp und Geschlecht

\begin{tabular}{lccc}
\hline & $\begin{array}{c}\text { Average daily } \\
\text { weight gains, } \mathrm{g} / \text { day }\end{array}$ & $\begin{array}{c}\text { Dressing percentage, } \\
\%\end{array}$ & $\begin{array}{c}\text { Warm carcass, } \\
\mathrm{kg}\end{array}$ \\
\hline Genotype & & & \\
$\quad$ Hungarian Merino $(n=60)$ & $323.01 \pm 4.82^{\mathrm{c}}$ & $50.74 \pm 0.27$ & $16.01 \pm 0.18$ \\
$\quad$ Hungarian Merino $\times$ Suffolk $\mathrm{F}_{1}(n=30)$ & $352.06 \pm 6.99^{\mathrm{c}}$ & $51.59 \pm 0.38$ & $16.34 \pm 0.27$ \\
$\quad$ Hungarian Merino $\times$ Ile de France $\mathrm{F}_{1}(n=30)$ & $358.24 \pm 6.76^{\mathrm{c}}$ & $51.34 \pm 0.38$ & $16.12 \pm 0.26$ \\
Gender & & & \\
$\quad$ Ram $(n=60)$ & $351.10 \pm 4.99^{\mathrm{a}}$ & $50.91 \pm 0.27$ & $16.24 \pm 0.19$ \\
Ewe $(n=60)$ & $337.78 \pm 4.97^{\mathrm{a}}$ & $51.57 \pm 0.27$ & $16.07 \pm 0.18$ \\
\hline a $P<0.05$, с $P<0.001$ & & &
\end{tabular}

Table 3 presents the collection of data of valuable carcass cuts from the right half (shoulders, round and cutlets). Out of the examined genotypes the total weight of all valuable carcass cuts of the Hungarian Merino $\times$ Suffolk $F_{1}$ lambs had shown significantly higher rates in comparison with the rates of the others genotypes (Hungarian Merino $\times$ lle de France $F_{1}: P<0.001$; Hungarian Merino: $P<0.001$ ). The proportion of the valuable 
carcass cuts had shown similar trends, where the biggest proportion was in Hungarian Merino $\times$ Suffolk $F_{1}$ lambs compared Hungarian Merino lambs $(P<0.001)$. Similar results established NAGY and DOMANOVSZKY (2006).

Concerning Hungarian Merino $\times$ Suffolk $F_{1}$ lambs had the heaviest shoulders $(1.79 \mathrm{~kg})$. It followed by Hungarian Merino $\times$ lle de France $F_{1}$ and finally the Hungarian Merino.

Focusing on the weight of round, Hungarian Merino $\times$ Suffolk $F_{1}(3.29 \mathrm{~kg})$ lambs were the bests. It was followed by the Hungarian Merino $\times$ lle de France $F_{1}(3.04 \mathrm{~kg})$ lambs and the Hungarian Merino lambs $(2.84 \mathrm{~kg})$.

The cutlet weight were similar between Hungarian Merino $\times$ Suffolk $F_{1}(1.75 \mathrm{~kg})$ and Hungarian Merino $\times$ lle de France $F_{1}(1.77 \mathrm{~kg})$ lambs, the smallest cutlets were in Hungarian Merino lambs (1.66 kg).

Gender not influenced the commercial carcass cuts (Table 3 ).

Table 3

LS means \pm standard error of lamb carcass cuts according to genotype and gender

Wertvolle Teilstücke und deren Anteile nach Genotyp und Geschlecht

\begin{tabular}{|c|c|c|c|c|c|}
\hline & Shoulder, kg & Round, kg & Cutlet, kg & $\begin{array}{c}\text { Valuable } \\
\text { carcass cuts, kg }\end{array}$ & $\begin{array}{c}\text { Valuable } \\
\text { carcass cuts, } \%\end{array}$ \\
\hline \multicolumn{6}{|l|}{ Genotype } \\
\hline Hungarian Merino $(n=60)$ & $1.65 \pm 0.02^{c}$ & $2.84 \pm 0.05^{\mathrm{ac}}$ & $1.66 \pm 0.03^{\mathrm{a}}$ & $6.15 \pm 0.07^{c}$ & $77.14 \pm 0.76^{c}$ \\
\hline $\begin{array}{l}\text { Hungarian Merino } \times \\
\text { Suffolk } F_{1}(n=30)\end{array}$ & $1.79 \pm 0.03^{c}$ & $3.29 \pm 0.07^{\mathrm{ac}}$ & $1.75 \pm 0.04$ & $6.84 \pm 0.09^{c}$ & $83.37 \pm 0.91^{c}$ \\
\hline $\begin{array}{l}\text { Hungarian Merino } \times \\
\text { Ile de France } \mathrm{F}_{1}(n=30)\end{array}$ & $1.68 \pm 0.03^{c}$ & $3.04 \pm 0.07^{\mathrm{a}}$ & $1.77 \pm 0.04^{\mathrm{a}}$ & $6.48 \pm 0.09^{c}$ & $81.06 \pm 0.88^{c}$ \\
\hline \multicolumn{6}{|l|}{ Gender } \\
\hline $\operatorname{ram}(n=60)$ & $1.72 \pm 0.02$ & $3.11 \pm 0.05$ & $1.75 \pm 0.03$ & $6.57 \pm 0.07$ & $80.82 \pm 0.79$ \\
\hline ewe $(n=60)$ & $1.70 \pm 0.02$ & $3.01 \pm 0.05$ & $1.71 \pm 0.03$ & $6.41 \pm 0.07$ & $80.22 \pm 0.78$ \\
\hline
\end{tabular}

The bone to meat ratio of the valuable carcass cuts (shoulder, round and cutlet) is collected into Table 4. Considering data it is appointed that Hungarian Merino $\times$ Suffolk $F_{1}$ and Hungarian Merino $\times$ lle de France $F_{1}$ lambs produced significantly more valuable meat in comparison with Hungarian Merinos $(\mathrm{P}<0.001)$. The proportions of valuable members related to $F_{1}$ 's were $75.4 \%-77.7 \%$. The valuable meat ratio of Hungarian Merino $\times$ lle de France $F_{1}$ was $77.7 \%$, significantly higher $(P<0.05)$ than the results belonging to Hungarian Merino (76.5\%) and Hungarian Merino $\times$ Suffolk $F_{1}(75.5 \%)$.

Gender influenced the bone to meat ration in shoulder, round and percent of valuable meat of carcass (Table 4). The ram carcasses had bigger percentage of bone to meat ration in shoulder and round and smaller percent of valuable meat than ewe. This observation corresponded with data published by GUTIERREZ et al. 2005.

Examining the conformation of slaughtered bodies (Figure 1) itss concluded that $22 \%$ of Hungarian Merino lambs are classified $» U$ « type, $65 \%$ of $\gg$ « and finally $13 \%$ of $\gg$ « category. $50 \%$ of Hungarian Merino $\times$ Suffolk $F_{1}$ lambs was classified $॥$ «, and $50 \%$ was "R«. $20 \%$ of lambs were $» U \ll$, the rest of $80 \%$ was $» R \ll$ of lambs of Hungarian Merino $\times$ lle de France $F_{1}$. Furthermore, $32 \%$ of rams and $22 \%$ of ewes were $» U \ll, 62 \%$ of rams and $68 \%$ of ewes of lambs were classified as »R« the rest of $6 \%$ of rams and $10 \%$ of ewe lambs did $\gg$ « . 
Table 4

LS means \pm standard error of lamb bone-meat ratio according to genotype and gender Knochen und wertvolle Fleischanteile

\begin{tabular}{|c|c|c|c|c|c|}
\hline \multirow{2}{*}{ Genotype } & \multirow[t]{2}{*}{ Shoulder, \% } & \multirow[t]{2}{*}{ Round, \% } & \multirow[t]{2}{*}{ Cutlet, \% } & \multicolumn{2}{|c|}{ Valuable meat, kg Valuable meat, $\%$} \\
\hline & & & & & \\
\hline $\begin{array}{l}\text { Hungarian Merino } \\
(n=60)\end{array}$ & $24.72 \pm 0.42^{\mathrm{ac}}$ & $22.33 \pm 0.42^{c}$ & $24.32 \pm 0.42^{\mathrm{a}}$ & $4.71 \pm 0.05^{c}$ & $76.49 \pm 0.30^{\mathrm{a}}$ \\
\hline $\begin{array}{l}\text { Hungarian Merino } \times \\
\text { Suffolk } F_{1}(n=30)\end{array}$ & $22.97 \pm 0.60^{\mathrm{a}}$ & $25.15 \pm 0.61^{c}$ & $26.17 \pm 0.61^{\mathrm{a}}$ & $5.08 \pm 0.08^{c}$ & $75.43 \pm 0.42^{\mathrm{ac}}$ \\
\hline $\begin{array}{l}\text { Hungarian Merino } \times \\
\text { lle de France } F_{1}(n=30)\end{array}$ & $21.21 \pm 0.59^{a c}$ & $21.51 \pm 0.58^{c}$ & $24.50 \pm 0.59$ & $5.06 \pm 0.08^{c}$ & $77.76 \pm 0.41^{\mathrm{ac}}$ \\
\hline $\begin{array}{l}\text { Gender } \\
\operatorname{ram}(n=\end{array}$ & & $+0.43^{\mathrm{a}}$ & & & \\
\hline ewe $(n=60)$ & $21.56 \pm 0.43^{c}$ & $22.35 \pm 0.42^{\mathrm{a}}$ & $25.03 \pm 0.43$ & $4.92 \pm 0.06$ & $77.25 \pm 0.30^{c}$ \\
\hline
\end{tabular}

a $P<0.05$, c $P<0.001$

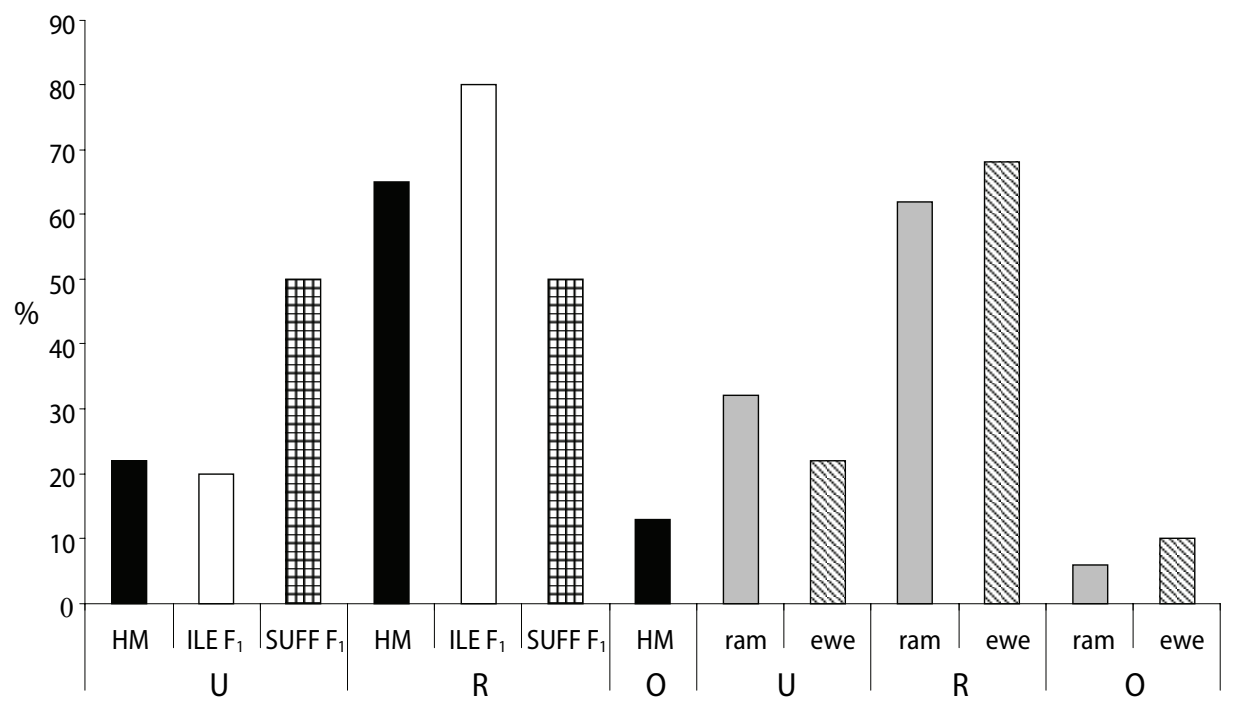

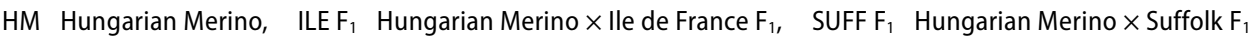

Figure 1

Percentage of genotypes and genders by S/EUROP conformation scores

Anteile Fleischigkeitsklassen nach Genotyp und Geschlecht

From the evaluation of the fat cover indices (Figure 2) $28 \%$ of Hungarian Merino lamb were ranked 2, while the rest of this breed was enrolled into class 3 (72\%). $65 \%$ of Hungarian Merino $\times$ Suffolk $F_{1}$ lambs were 2, 35\% of them got 3 class. $50 \%$ of Hungarian Merino $\times$ lle de France $F_{1}$ lambs received 2 and $3.46 \%$ of rams got into $2,54 \%$ into 3 and $34 \%$ of ewes got 2 , till the rest of $66 \%$ made 3 . Gender influenced the S/EUROP conformation and fat covered. The ram carcasses had higher muscularity and lower fat covered than ewe lambs. These are in agreement with the findings of TOLDI et al. (1999); PAJOR et al. (2004) and NAGY et al. (2006). 


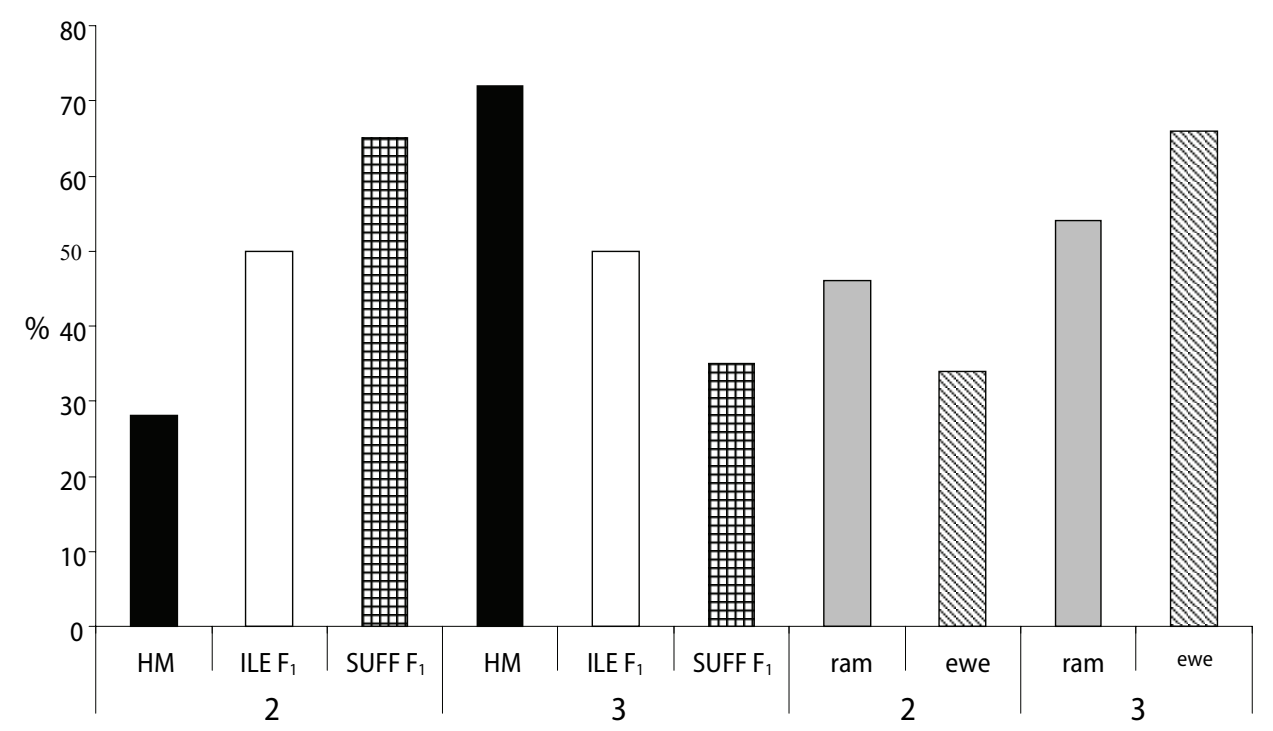

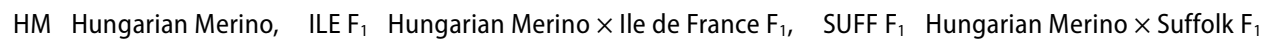

Figure 2

Percentage of genotypes and genders by S/EUROP fat cover scores

Anteile Fettgewebeklassen nach Genotyp und Geschlecht

The results suggested that the crossed genotypes were shown better muscularity (S/EUROP) conformation than pure Hungarian Merino. Above results are confirmed by others authors' reported where Merino was the initial breed and Suffolk, German Merino, German Blackheaded were the meat breeds (MOLNÁR et al. 1999, LIPECZKA et al. 2001, ZUPP 2003, NAGY et al. 2006). The crossed genotypes were characterized with the most beneficial parameters of meat performance.

Summarising the results, both cross breed genotypes overdone the pure breed Hungarian Merino concerning weight gain. The slaughter performance and the S/EUROP conformation were the highest in Hungarian Merino $\times$ Suffolk $F_{1}$. Presently, the results are shown in Hungarian practice, that Hungarian Merino lambs is not eligible fattening to great live body weight $(30 \mathrm{~kg})$. Meat type breeds, their $\mathrm{F}_{1}$ lambs respectively, are recommended to be raised $30 \mathrm{~kg}$ live weight above, utilizing their advantageous gain capacities better.

\section{Acknowledgements}

This work was supported by Ministry of Education (4/031/2001 NKFP; OMFB 00790/2003). The authors acknowledge Tibor Kószó for assistance with this experiment.

\section{References}

Brzostowski H, Tanski Z (2006) Nutritional value of meat of Pomeranian breed lambs and crossbreds of Blackheaded and texel rams. Arch Tierz 49 SI, 345-52

Brzostowski H, Tywonczuk J, Tanski Z (2004) Indexes of nutritive value of meat from Pomeranian lambs and crossbreeds of Pomeranian ewes with meat breed rams. Arch Tierz $47 \mathrm{SI}, 175-82$ 
Cloete JJE, Cloete SWP, Olivier JJ, Hoffman LC (2007) Terminal crossbreeding of Dorper ewes to Ile de France Merino Landsheep and SA Mutton Merino sires Ewe production and lamb performance. Small Rumin Res 69, 28-35

Freudenreich P, Dobrowolski A, Branscheid W (2001) Evaluation of lamb carcass quality - a critical investigation of the EUROP-classification system. Arch Tierz 44 (2001) SI, 336-43

Gonyou HW, Stookey JM, McNeal LG (1985) Effects of double decking and space allowance on the performance and bahcionin of feder lambs. J Anim Sci 60 (1985) 1110-6

Gutierrez J, Rubio MS, Mendez RD (2005) Effects of crossbreeding Mexican Pelibuey sheep with Rambouillet and Suffolk on carcass traits. Meat Sci 70, 1-5

Kefelegn K, Süss R, Mielenz N, Schüler L, Lengerken von G (1998) Genetic and phenotypic paramenter estimates for growth and carcass value traits of sheep. Arch Tierz 41, 463-72 [in German]

Korman K (2001) The effect of feeding system (ad libitum or rationed) on the feed conversion rate and weight gains of Merino ram lambs. Arch Tierz 44 SI, 240-8

Korman K (2002) The effect of the method of nutritive value determination of the ration and its physical form on the course and economic efficiency of lamb fattening. Ann Univ Mariae Curie Sklodowska Sect EE Zootechn 20, 149-56

Lipecka C, Gruszecki T M, Pieta M, Szymanowska A, Patkowski K, Szimanowski M, Junkuszew A (2001) Meat performance of hybrid ram lambs with different shares of a prolific breed. Arch Tierz 44, 370-6

Lengyel A, Toldi GY (2003) Relationship between S/EUROP conformation and slaughter value in sheep. Magyar juhászat és kecsketenyésztés 12, 3-6 [in Hungarian]

Lengyel A, Toldi GY, Mezőszentgyörgyi D (1999) Genetics stores in sheep meat production. Magyar juhászat és kecsketenyésztés 8, 4-7 [in Hungarian]

Martyniuk E, Olech W, Klewiec J (2001) Body weight and in-vivo assessed slaughter performance in Olkuska sheep lambs. Arch Tierz 44 SI 377-84

Molnár GY, Jávor A, Veress L (1999) Fattening and slaughtering performance of endproduct lambs from milksheep crosses. 1st Paper: Fattening ability. Állattenyésztés és Takarmányozás 48, 213-32

Nagy L, Székely P, Domanovszky Á (2005) Results of sheep performance test 2005. Országos Mezőgazdasági Minősítő Intézet Budapest [in Hungarian]

Nagy L, Domanovszky Á (2006) Results of sheep performance test 2006. Országos Mezőgazdasági Minősítő Intézet Budapest [in Hungarian]

Osikowski M, Borys B (1976) Effect on production and carcass quality characteristics of whether lambs of crossing Blackheaded Mutton Ile de France and Texel rams with Polish Merino ewes. Livest Prod Sci 4, 343-9

Pajor F, Póti P, Láczó E (2004) Comparison of slaughter performance of Hungarian Merino German Mutton Merino and German Blackheaded lambs. Acta Ovariensis 46, 77-83

Paraponiak P, Roborzynski M (2001) The use of Tiroler Bergschaf and Weisses Alpenschaf for the production of slaughter lambs in Polish mountainous areas. Arch Tierz 44, 391-7

Pompa-Roborzynski M, Kedzior W (2006) Effects of crossbreeding and different feeding systems on slaughter value and meat quality of lamb reared in natural pastures of the Beskid Sadecki Mountains. Arch Tierz 49 SI, 268-74

Schwulst FJ (1986) Lifetime production performance by Suffolk $\times$ Rambuillet ewes in Northwestern Kansas. Keeping up with research 91. Kansas State University, Agricul exp stat contr No 87-80-S

Suess R, Heylen K, Lengerken von G (2000) The effect of Booroola on fat content and fat quality of carcasses in crosses with German Mutton Merinos. Arch Tierz 43, 45-56 [in German]

Toldi Gy, Mezőszentgyörgyi D, Lengyel A (1999) Connection between sheep carcasses', S/EUROP qualification and several cutting parameters. Acta Agraria Kaposvariensis 3, 25-34

Zupp W (2003) Realise slaughter lambs for the market by cross breeding. Arch Tierz 46 SI, 78-83

Received 21 October 2008, accepted 17 December 2008.

Corresponding author:

FERENC PAJOR

email: pajor.ferenc@mkk.szie.hu

Institute of Animal Husbandry, Faculty of Agricultural and Environmental Sciences, Szent István University, Páter K. 1., H-2100 Gödöllö, Hungary 